\title{
СЕЛЕКТИВНОЕ ИНГИБИРОВАНИЕ ОКСИГЕНАЗНОЙ АКТИВНОСТИ АLОХ15 ЗАМЕЩЕННЫМИ 2-(4-МЕТОКСИ)АРИЛИНДОЛАМИ
}

\section{Р.Р. Шафиуллина, В.В.Аксенов, А.Б. Голованов, А.М. Журавлев, И.В. Иванов}

ФГБОУ ВО «МИРЭА - Российский технологический университет», 119454, Россия, Москва, Проспект Вернадского, д. 78.

DOI: 10.19163/MedChemRussia2021-2021-388

E-mail: shafiullina.rania@mail.ru

Липоксигеназы образуют семейство ферментов перекисного окисления липидов, которые участвуют в ряде физиологических процессов: патогенезе воспалительных, гиперпролиферативных и нейродегенеративных заболеваний. Создание эффекторов ALOX15 в настоящее время является важной целью биомедицинских исследований в силу разнонаправленных свойств фермента; метаболиты окисления ALOX15 проявляют как про-,так и противовоспалительные свойства.

Нами была разработана методика получения замещенных 2-(4-метокси)арилиндол-сульфомоилкарбоматов, являющихся селективными ингибиторами линолеат-оксигеназной активности ALOX15. 2-Арилиндолы получали по реакции Фишера, подвергая циклизации фенилгидразон замещенного ацетофенона в полифосфорной кислоте. Было выявлено, что наличие СН30-группы в 4-положении анилинового заместителя индола играет ключевую роль в обеспечении избирательного аллостерического ингибирования линолеат-оксигеназной активности ALOX15. Структуры соединений подтверждены данными ${ }^{1} \mathrm{H},{ }^{13} \mathrm{C}$ - ЯМР спектроскопии, масс-спектрометрии, ИК-спектроскопии и элементного анализа.

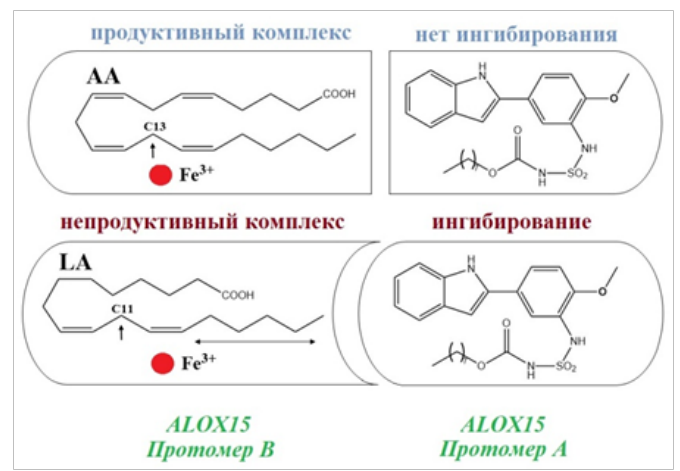

Pис. 1. Механизм селективного субстратного ингибирования.

Работа выполнена при финансовой поддержке РФФИ (проект № 19-54-12002). 